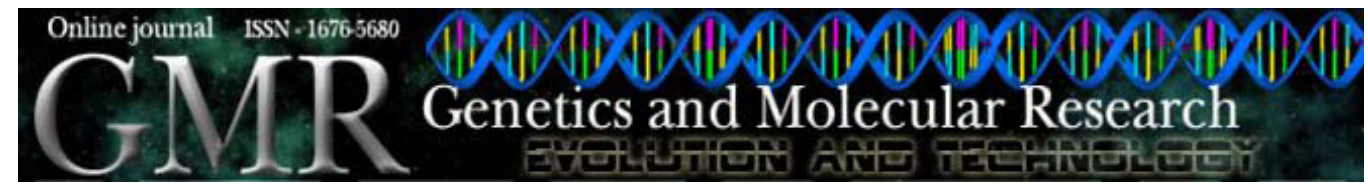

\title{
Karyotypic evolution trends in Rhamdia quelen (Siluriformes, Heptapteridae) with considerations about the origin and differentiation of its supernumerary chromosomes
}

\author{
C. Garcia ${ }^{1}$, C. Oliveira ${ }^{2}$ and L.F. Almeida-Toledo ${ }^{1}$
}

${ }^{1}$ Departamento de Genética e Biologia Evolutiva, Universidade de São Paulo, São Paulo, SP, Brasil

${ }^{2}$ Departamento de Morfologia,

Universidade Estadual Paulista Júlio de Mesquista Filho, Botucatu, SP, Brasil

Corresponding author: C. Garcia

E-mail: caro199bio@yahoo.com

Genet. Mol. Res. 9 (1): 365-384 (2010)

Received November 24, 2009

Accepted December 14, 2009

Published March 2, 2010

\begin{abstract}
Among catfish species of the genus Rhamdia reported for the Brazilian territory, $R$. quelen is the most widespread, being found in nearly all hydrographic basins of Brazil. Nowadays, $R$. quelen is a synonym for at least 47 other species in this genus, its taxonomic status still being controversial. The available cytogenetic reports show a wide variation in the karyotypic macrostructure, with the frequent presence of supernumerary chromosomes. The remarkable cytogenetic variability associated with taxonomic issues in this species indicates that $R$. quelen is actually a species complex.
\end{abstract}


In order to carry out a wide comparative cytogenetic study in $R$. quelen from southern and southeastern Brazil and examine a species complex, we analyzed the chromosomes of 14 populations from the main hydrographic basins of these two regions. Using classic and molecular cytogenetic techniques, we found seven distinct karyotypic formulae, all bearing $2 \mathrm{n}=58$ chromosomes. Supernumerary chromosomes were present in most of the populations; their number, size and C-banding pattern allowed us to differentiate populations with similar karyotypic compositions. We examined patterns of chromosomal evolution as well as the probable mechanisms involved in the origin and morphological differentiation of their supernumerary chromosomes.

Key words: Karyotype; Supernumerary chromosomes; Rhamdia; Heterochromatin; Non-disjunction

\section{INTRODUCTION}

The Neotropical ichthyofauna is extremely rich and diverse, comprising $50 \%$ of the world's freshwater species. According to Reis et al. (2003), there are about 6000 fish species described in the Neotropics, distributed among 71 families and 25 orders. Heptapteridae is a strictly Neotropical fish family, comprising small- to medium-sized catfishes. Some species are widespread throughout this region, being found from southern Mexico to southern Argentina (Pinna, 1998), including, for instance, Rhamdia quelen (Silfvergrip, 1996).

Rhamdia quelen is one of the 12 valid species in the genus Rhamdia (Bockmann, 2007), being currently recognized as a synonym for 47 previously described species in the Central and South Americas, including $R$. voulezi, $R$. branneri, $R$. hilari, and $R$. sapo (Silfvergrip, 1996). As it is the species with the largest distribution range in this genus, $R$. quelen is also the most widely studied, including both morphological and cytogenetic research.

Morphological studies carried out by Silfvergrip (1996), in the last review of the genus Rhamdia, showed that specimens of $R$. quelen exhibit a series of morphological differences when specimens from distant geographic regions are compared. However, this author points out that these differences might be a consequence of sampling constraints, inasmuch as when more samples along the occurrence range of this species become available, the morphological differences among them are insufficient for their distinction. Therefore, he proposes that $R$. quelen is the only Rhamdia representative whose distribution includes the entire Neotropical region, sometimes living in sympatry with congeneric species.

From a cytogenetic point of view, six species of Rhamdia have been chromosomally characterized (Garcia et al., 2003). However, following the taxonomic review by Silfvergrip (1996), all these species were summarized into R. quelen, and thus this would be the only Rhamdia species for which cytogenetic information is available. The cytogenetic data show a wide variation of the karyotype macrostructure, with differences in the karyotypic formulae of the various populations (Garcia et al., 2003), which reinforces the 
hypothesis of the existence of a species complex for $R$. quelen.

Another remarkable cytogenetic feature observed in $R$. quelen is the frequent presence of supernumerary or B chromosomes, responsible for intra- and interindividual variation in the chromosome number in the various populations (Garcia et al., 2003). Supernumerary chromosomes are considered to be one of the major dilemmas in fish cytogenetics, because their function and origin remain unclear; they seem to be dispensable genetic elements with no visible phenotypic effects on the carriers and would therefore be neutral to natural selection (Carvalho et al., 2008).

Supernumerary chromosomes are relatively frequent in fish species, and new reports about their presence in fish species continue to appear as new populations are analyzed. The largest number of observations of such chromosomes has been reported for the order Characiformes, followed by Siluriformes and, at a lower frequency, for other fish groups. Within the Siluriformes, supernumerary chromosomes have already been reported in representatives of the families Callichthyidae, Heptapteridae, Loricariidae, Pimelodidae, and Trichomychteridae (Carvalho et al., 2008).

The supernumerary chromosomes present in some populations of $R$. quelen vary in size, shape and C-banding pattern, being composed, in most cases, of medium-sized metacentric chromosomes that can be totally (Vissoto et al., 1999; Garcia et al., 2003) or partially heterochromatic (Maistro et al., 2002), or else entirely euchromatic (Abucarma and Martin-Santos, 2001; Moraes et al., 2007). Different from other Siluriformes species, in which supernumerary chromosomes are considered to be isolated events, the high frequency of these chromosomes in $R$. quelen suggests they are a cytogenetic feature of this species.

Adopting the classification proposed by Silfvergrip (1996), our goal was to carry out an extensive comparative cytogenetic analysis of several populations of $R$. quelen from the main hydrographic basins in southern and southeastern Brazil, in order to determine the trends of karyotypic evolution within this species and provide a better characterization of the supernumerary chromosomes present in these populations, inferring about their possible origin and evolution.

\section{MATERIAL AND METHODS}

Fourteen populations of $R$. quelen from the main hydrographic basins in the Brazilian States of Paraná, São Paulo and Rio de Janeiro were analyzed (Table 1). Mitotic chromosomes were obtained following a technique adapted from Gold et al. (1990), using anterior kidney cells of the specimens and Hank's medium for precise control of colchicine activity in vitro. Chromosomal morphology was determined according to the arm ration proposed by Levan et al. (1964) and the fundamental number (FN) was calculated taking into account the fact that metacentric $(\mathrm{m})$, submetacentric $(\mathrm{sm})$ and subtelocentric (st) chromosomes are two-armed and acrocentric (a) elements are onearmed. The morphological classification of the supernumerary chromosomes (S) also followed Levan et al. (1964), although these elements were grouped separate from the standard karyotype.

Identification of nucleolar organizer regions (NORs) by silver nitrate staining followed the procedure described by Howell and Black (1980), while chromosomal staining with 
GC-specific fluorochromes was done using chromomycin $\mathrm{A}_{3}\left(\mathrm{CMA}_{3}\right)$, according to Schmid (1980), with slight modifications. The constitutive heterochromatin segments were detected by C-banding according to Sumner (1972); the exposure time to barium hydroxide was adjusted for each population, ranging from $45 \mathrm{~s}$ to $1 \mathrm{~min}\left(\right.$ at $42^{\circ} \mathrm{C}$ ). Fluorescent in situ hybridization (FISH) was used to identify the number and location of ribosomal genes, according to the procedure described by Pinkel et al. (1986), using 18S rDNA (Hatanaka and Galetti, 2004) and 5S rDNA (Martins and Galetti Jr., 1999) probes.

\section{RESULTS}

Approximately 50 cells were analyzed per specimen. Chromosomal counts allowed establishing a diploid number of $2 \mathrm{n}=58$ for all populations. All individuals in the populations bearing supernumerary chromosomes presented such additional chromosomes, which were responsible for intra- and interindividual variation in the chromosome number (Figures 1-7). We identified seven chromosomal formulae, so that some populations, although they shared the same karyotypic pattern, differed in the type and/or number of supernumerary chromosomes (Table 1).

\begin{tabular}{|c|c|c|c|c|c|c|}
\hline Locality & $\begin{array}{l}\text { Number of } \\
\text { individuals }\end{array}$ & $2 \mathrm{~N}$ & $\begin{array}{l}\text { Karyotype } \\
\text { formula }\end{array}$ & FN & $\begin{array}{l}\text { Number/size of } \\
\text { supernumerary } \\
\text { chromosomes }\end{array}$ & $\begin{array}{c}\text { C-banding pattern } \\
\text { of supernumerary } \\
\text { chromosomes }\end{array}$ \\
\hline $\begin{array}{l}\text { Cascavel/PR - Oeste river (BP) } \\
\text { (S 2509'16.44"/ W } 53^{\circ} 19^{\prime} 40^{\prime \prime)}\end{array}$ & $5 \circ, 9{ }^{\lambda}$ & 58 & $36 \mathrm{~m}+10 \mathrm{sm}+12 \mathrm{st}$ & 116 & 0 & - \\
\hline $\begin{array}{l}\text { Cascavel/PR - Sangão stream (BP) } \\
\left(\mathrm{S} 25^{\circ} 08^{\prime} 6.24^{\prime \prime} / \mathrm{W} 53^{\circ} 21^{\prime} 37.5^{\prime \prime}\right)\end{array}$ & $6 \circ, 6 \AA$ & 58 & $32 \mathrm{~m}+8 \mathrm{sm}+12 \mathrm{st}+6 \mathrm{a}$ & 110 & 0-1 medium-sized & 2 \\
\hline $\begin{array}{l}\text { Angra dos Reis/RJ (PS) } \\
\left.\text { (S } 22^{\circ} 53^{\prime} 11.4^{\prime \prime} / \mathrm{W} 44^{\circ} 16{ }^{\prime} 24.2^{\prime \prime}\right)\end{array}$ & $2 \circ, 6{ }^{\circledR}$ & 58 & $40 m+10 s m+8 s t$ & 116 & 0 & - \\
\hline $\begin{array}{l}\text { São José River/RJ (PS) } \\
\text { (S 22²9'24"/ W 44.3³6’20.7”) }\end{array}$ & $4+$ & 58 & $36 m+14 s m+8 s t$ & 116 & 0-1 medium-sized & 1 \\
\hline $\begin{array}{l}\text { Paraíba do Sul River/RJ (PS) } \\
\left(\mathrm{S} 21^{\circ} 38^{\prime} 4.26 " / \mathrm{W} 42^{\circ} 02^{\prime} 1.92^{\prime \prime}\right)\end{array}$ & 19 & 58 & $36 m+14 s m+8 s t$ & 116 & 0-1 medium-sized & 1 \\
\hline $\begin{array}{l}\text { Araras/SP (AP) } \\
\left(\mathrm{S} 22^{\circ} 22^{\prime} 59.6^{\prime \prime} / \mathrm{W} 47^{\circ} 25^{\prime} 49.5^{\prime \prime}\right)\end{array}$ & $3+4 \hat{\jmath}, 1 ?$ & 58 & $40 m+10 s m+8 s t$ & 116 & $0-5$ small & 1 \\
\hline $\begin{array}{l}\text { Botucatu/SP - Capivara River (AP) } \\
\left(\mathrm{S} 22^{\circ} 52^{\prime} 12.5^{\prime \prime} / \mathrm{W} 48^{\circ} 22^{\prime} 16.2^{\prime \prime}\right)\end{array}$ & $1 \hat{\jmath}$ & 58 & $44 m+12 s m+2 s t$ & 116 & 0-1 medium-sized & 2 \\
\hline $\begin{array}{l}\text { Colina/SP (AP) } \\
\text { (S 2044'38.1"/ W 48³4’20") }\end{array}$ & 19 & 58 & $36 m+10 s m+12 s t$ & 116 & $0-5$ small & 1 \\
\hline $\begin{array}{l}\text { Guapiara/SP (AP) } \\
\text { (S 2411'30.18"/ W 48³2'0.8") }\end{array}$ & $9, 2 \hat{\jmath}$ & 58 & $36 m+10 s m+12 s t$ & 116 & 0 & - \\
\hline $\begin{array}{l}\text { Iguape/SP (RI) } \\
\text { (S 24³6'1.6”/ W 4752’32.6”) }\end{array}$ & 19 & 58 & $36 m+10 s m+12 s t$ & 116 & 0 & - \\
\hline $\begin{array}{l}\text { Ipeúna/SP - Passa Cinco River (AP) } \\
\text { (S } 22^{\circ} 25^{\prime} 50.7^{\prime \prime} / \mathrm{W} 47^{\circ} 41^{\prime} 47.1^{\prime \prime)}\end{array}$ & 4 ㅇ, $1 \delta^{\lambda}$ & 58 & $34 m+16 s m+8 s t$ & 116 & 0-4 medium-sized & 1 \\
\hline $\begin{array}{l}\text { Mariápolis/SP - Fortuna stream (AP) } \\
\left(\mathrm{S} 21^{\circ} 44^{\prime} 35.3 " / \mathrm{W} 51^{\circ} 18^{\prime} 28.9^{\prime \prime}\right)\end{array}$ & $12+, 4 \hat{\jmath}$ & 58 & $40 m+10 s m+8 s t$ & 116 & 0-1 medium-sized & 1 \\
\hline $\begin{array}{l}\text { Piquete/SP (PS) } \\
\left.\text { (S 22³2'52.4”/ W } 45^{\circ} 11^{\prime} 19.4^{\prime \prime}\right)\end{array}$ & 2 ㅇ, $10^{\lambda}$ & 58 & $40 m+10 s m+8 s t$ & 116 & $0-2$ small & 3 \\
\hline $\begin{array}{l}\text { Sto. Antônio do Pinhal/SP (PS) } \\
\left.\text { (S } 22^{\circ} 49^{\prime} 58.9^{\prime \prime} / \mathrm{W} 45^{\circ} 44^{\prime} 8^{\prime \prime}\right)\end{array}$ & $5 \hat{\jmath}$ & 58 & $30 \mathrm{~m}+14 \mathrm{sm}+12 \mathrm{st}+2 \mathrm{a}$ & 114 & $0-2$ small & 3 \\
\hline
\end{tabular}

$\mathrm{AP}=$ Upper Paraná River basin; BP = Lower Paraná River basin; PS = Paraíba do Sul River basin; RI = Ribeira do Iguape. $\mathrm{FN}$ = fundamental number. C-banding: (1) partially heterochromatic chromosomes - presenting heterochromatin only on terminal regions of both arms; (2) totally euchromatic; (3) totally heterochromatic. $\mathrm{m}=$ metacentric; $\mathrm{sm}=$ submetacentric; $\mathrm{st}=$ subtelocentric; $\mathrm{a}=$ acrocentric. 
A
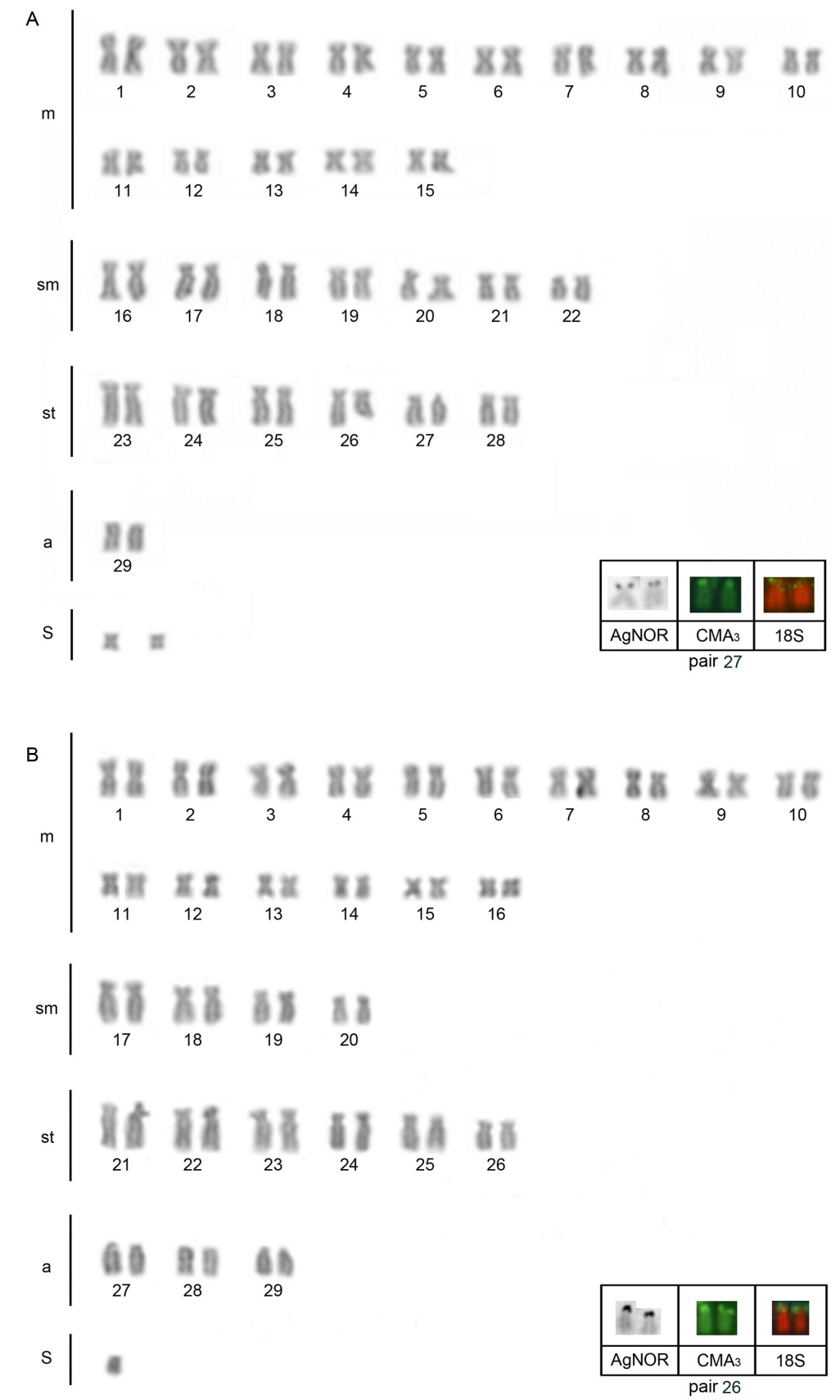

Figure 1. Giemsa-stained karyotypes in populations of Rhamdia quelen from A. Santo Antônio do Pinhal and $\mathbf{B}$. Sangão stream, Cascavel. Within the boxes: the NOR-bearing pair after silver nitrate staining (AgNOR), $\mathrm{CMA}_{3}$ staining and FISH with $18 \mathrm{~S}$ rDNA probe. 
C. Garcia et al.

370

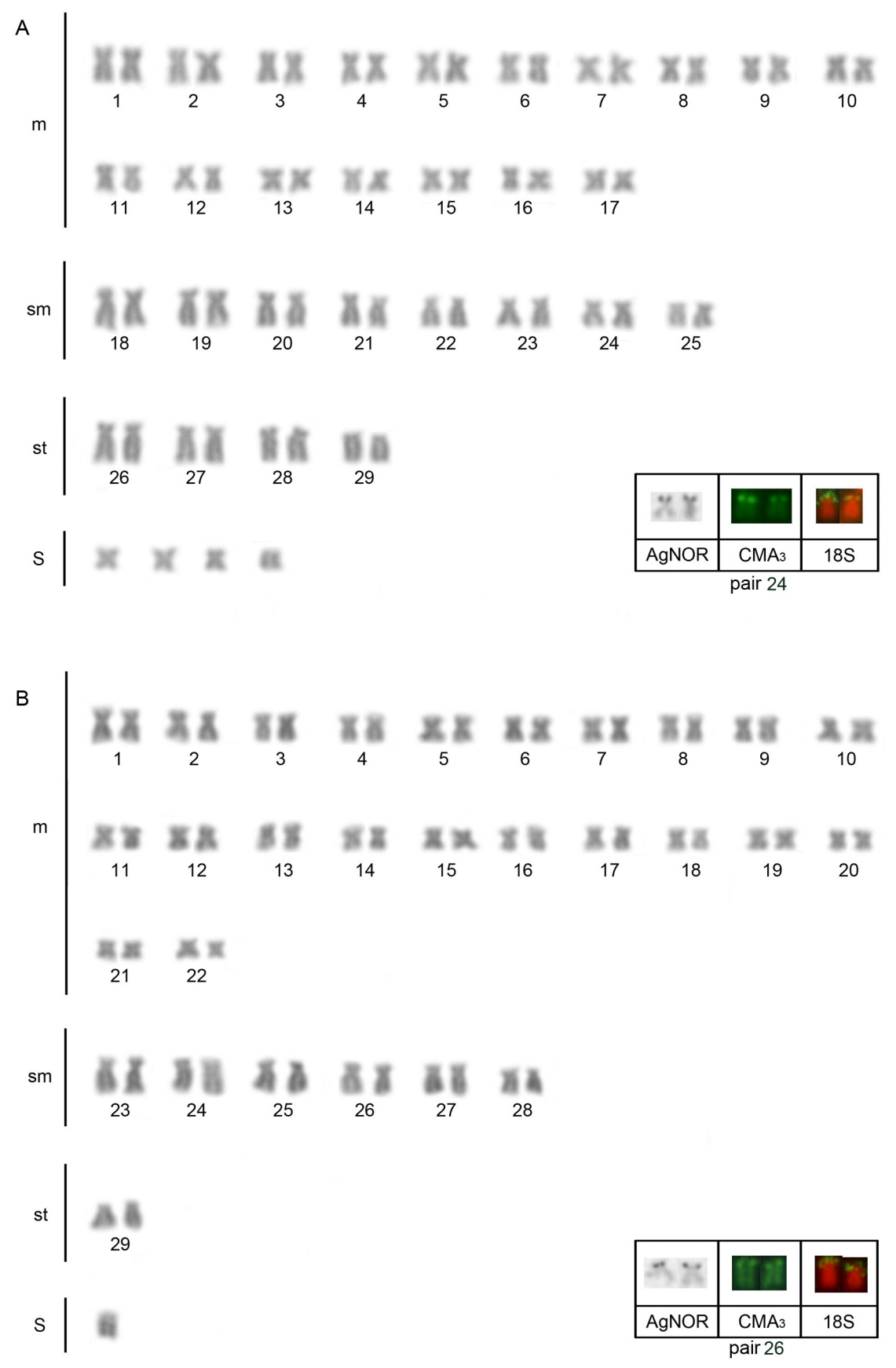

Figure 2. Giemsa-stained karyotypes in populations of Rhamdia quelen from A. Ipeúna and B. Botucatu. Within the boxes: the NOR-bearing pair after silver nitrate staining (AgNOR), CMA 3 staining and FISH with $18 \mathrm{~S}$ rDNA probe.

Genetics and Molecular Research 9 (1): 365-384 (2010)

CFUNPEC-RP www.funpecrp.com.br 


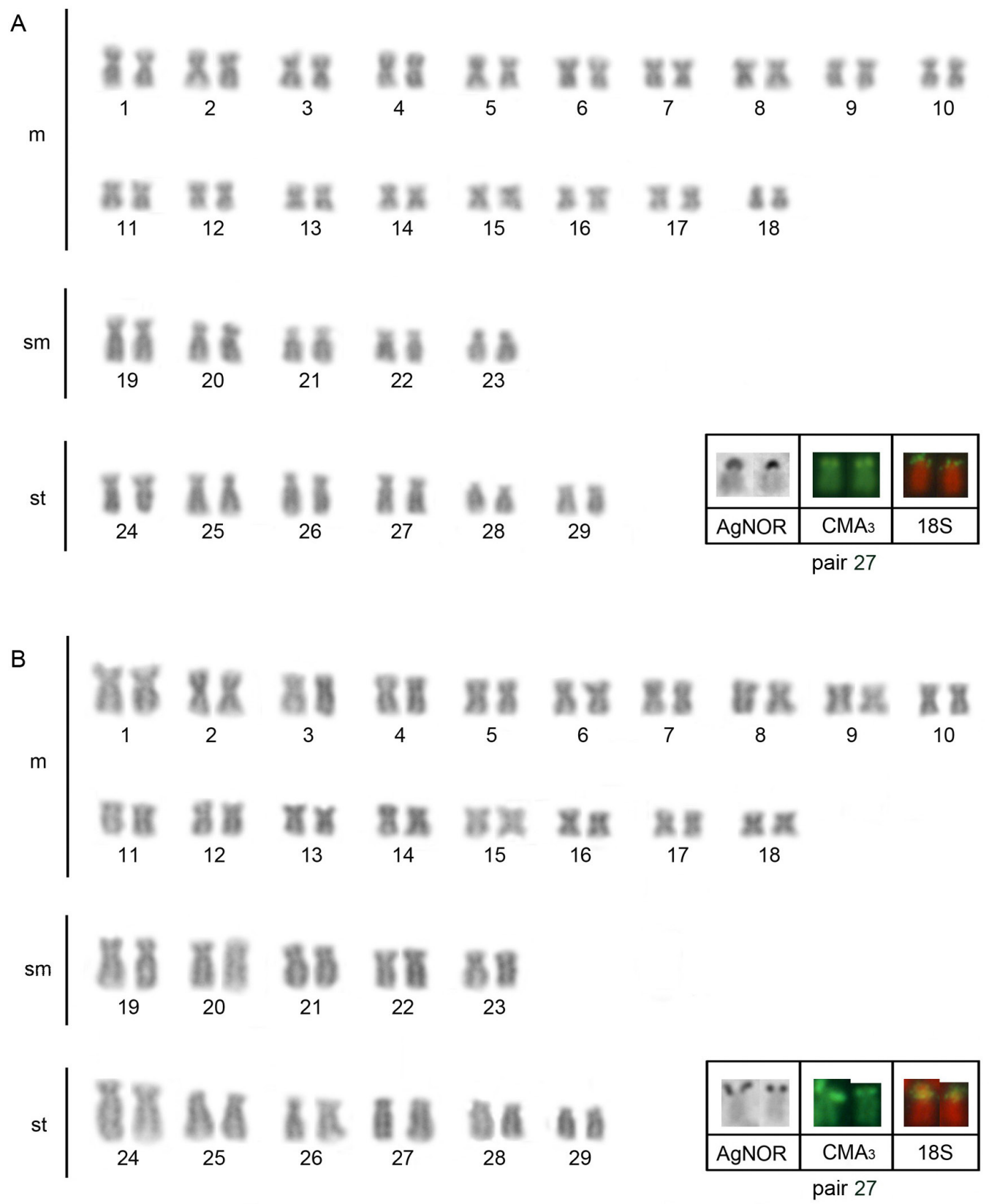

Figure 3. Giemsa-stained karyotypes in populations of Rhamdia quelen from A. Oeste river - Cascavel and B. Iguape. Within the boxes: the NOR-bearing pair after silver nitrate staining (AgNOR), $\mathrm{CMA}_{3}$ staining and FISH with $18 \mathrm{~S}$ rDNA probe. 
C. Garcia et al.
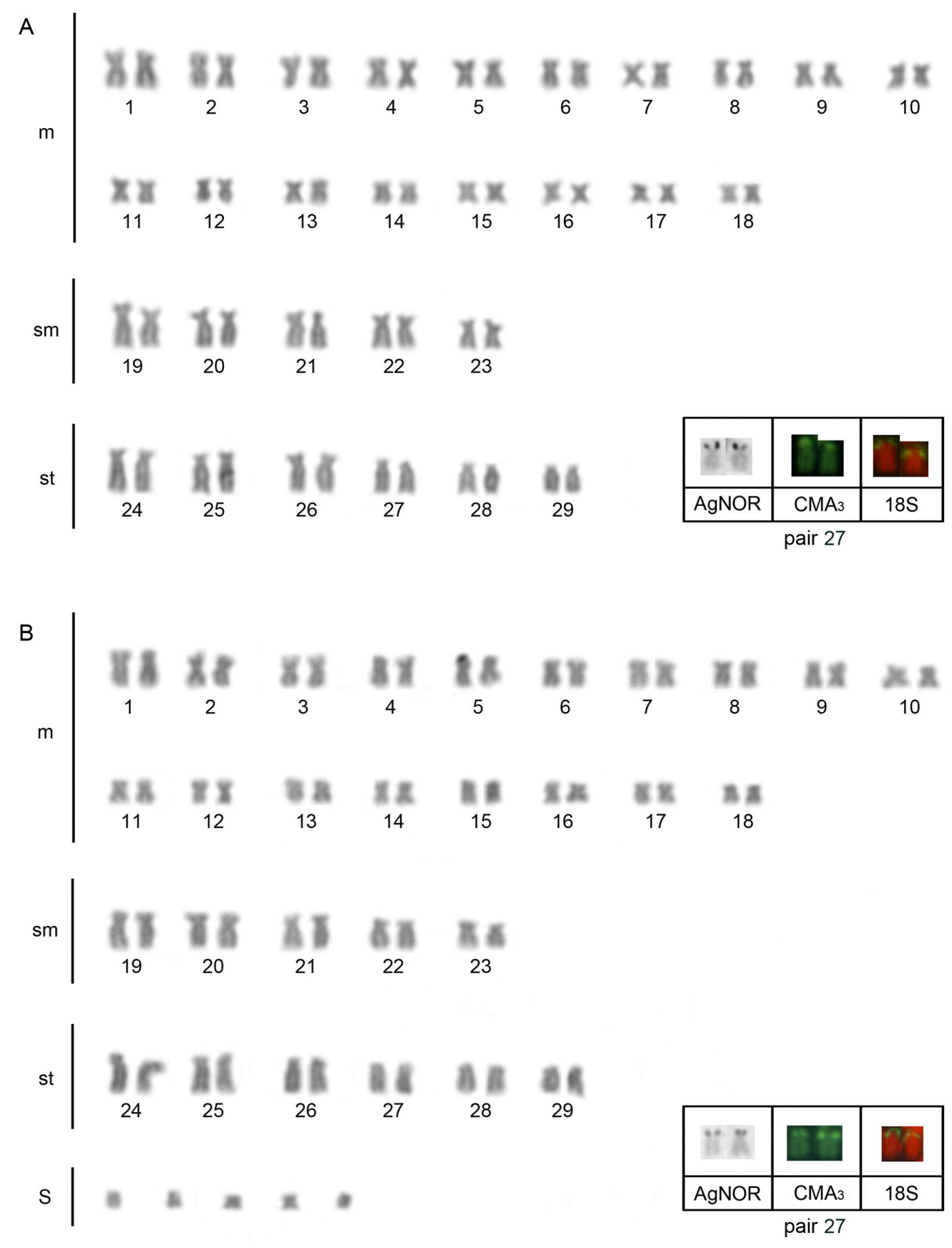

Figure 4. Giemsa-stained karyotypes in populations of Rhamdia quelen from A. Guapiara and B. Colina. Within the boxes: the NOR-bearing pair after silver nitrate staining (AgNOR), $\mathrm{CMA}_{3}$ staining and FISH with $18 \mathrm{~S}$ rDNA probe. 

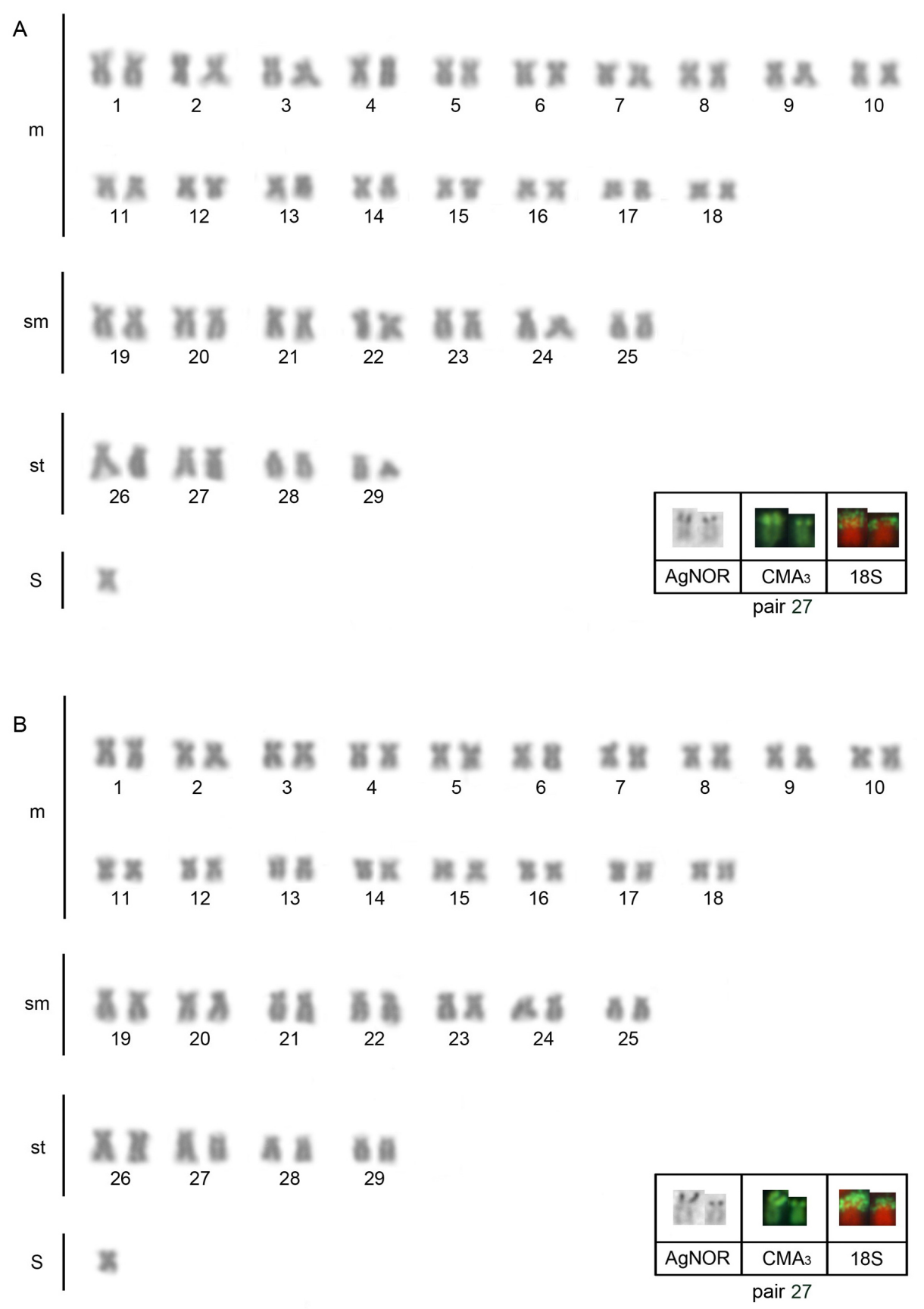

Figure 5. Giemsa-stained karyotypes in populations of Rhamdia quelen from A. São José River and B. Paraíba do Sul River. Within the boxes: the NOR-bearing pair after silver nitrate staining (AgNOR), $\mathrm{CMA}_{3}$ staining and FISH with $18 \mathrm{~S}$ rDNA probe. 
C. Garcia et al.
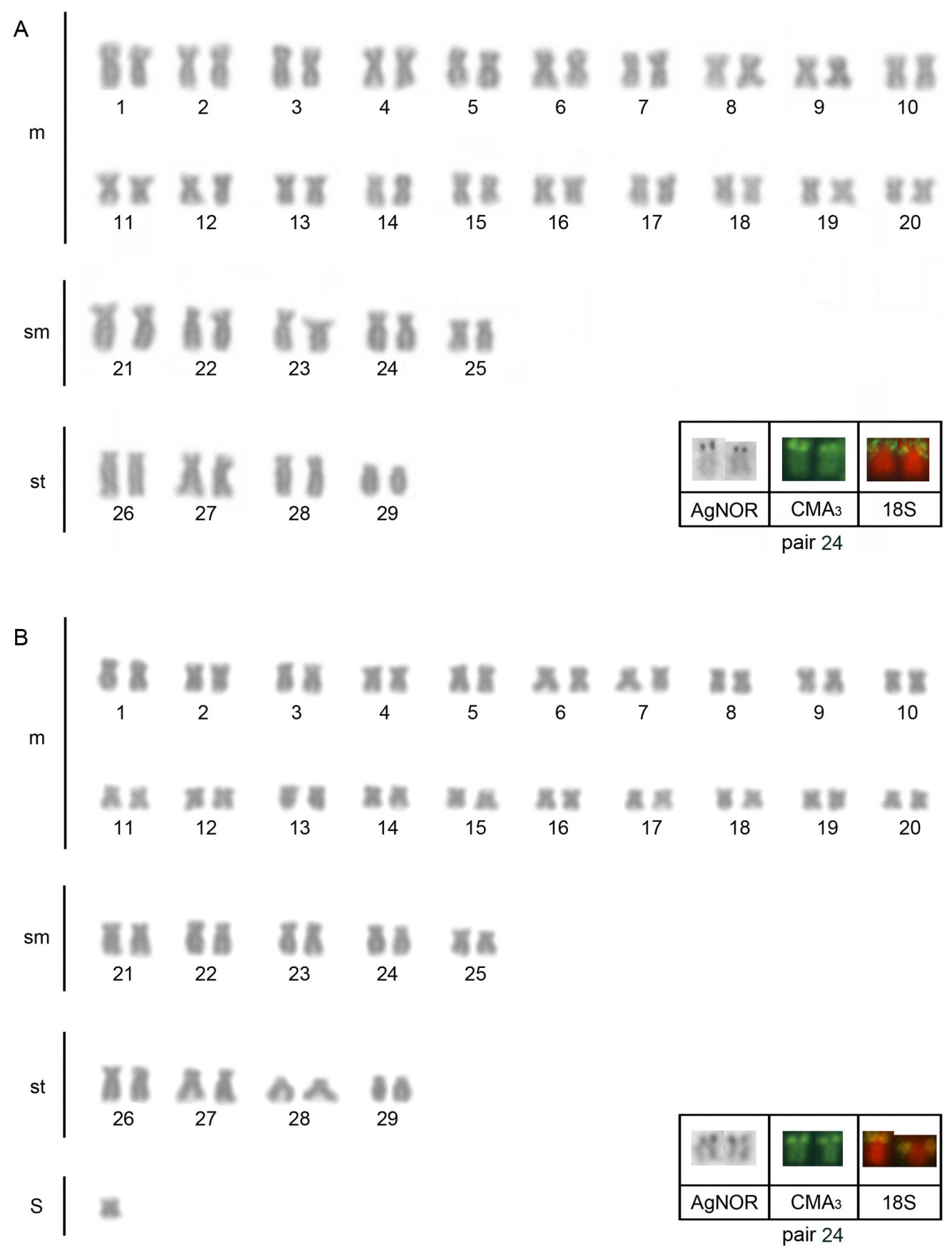

Figure 6. Giemsa-stained karyotypes in populations of Rhamdia quelen from A. Angra dos Reis and B. Mariápolis. Within the boxes: the NOR-bearing pair after silver nitrate staining (AgNOR), $\mathrm{CMA}_{3}$ staining and FISH with $18 \mathrm{~S}$ rDNA probe. 


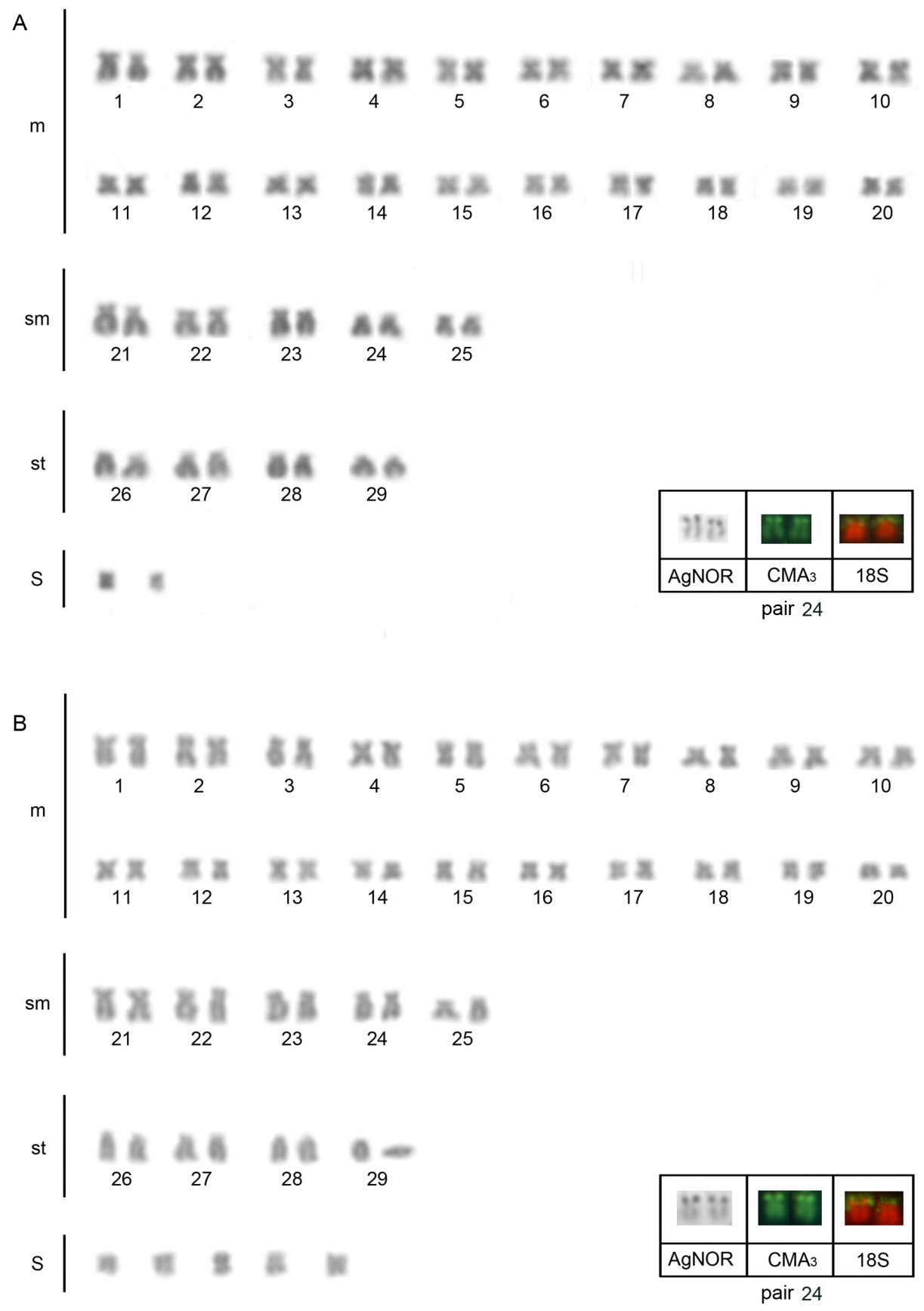

Figure 7. Giemsa-stained karyotypes in populations of Rhamdia quelen from A. Piquete and B. Araras. Within the boxes: the NOR-bearing pair after silver nitrate staining (AgNOR), $\mathrm{CMA}_{3}$ staining and FISH with $18 \mathrm{~S}$ rDNA probe. 
Both GC-specific fluorochrome and silver nitrate staining, as well as FISH with $18 \mathrm{~S}$ rDNA probes, showed a single NOR system in $R$. quelen. The NORs were located on short arms of a pair of submetacentric or subtelocentric chromosomes, depending on the population. Apparently, the NOR-bearing pair was identical among the populations with the same karyotypic formulae (Figures 1-7, boxes).

The number and location of $5 \mathrm{~S}$ rRNA genes proved to be conserved in the populations, with fluorescent signals identified in the pericentromeric region on the long arms of a pair of metacentric chromosomes. The population from Mariápolis was the only one that had an additional $5 \mathrm{~S}$ rDNA-bearing pair, characterized by a small pericentromeric mark on the short arms of a large subtelocentric pair (Figure 8).
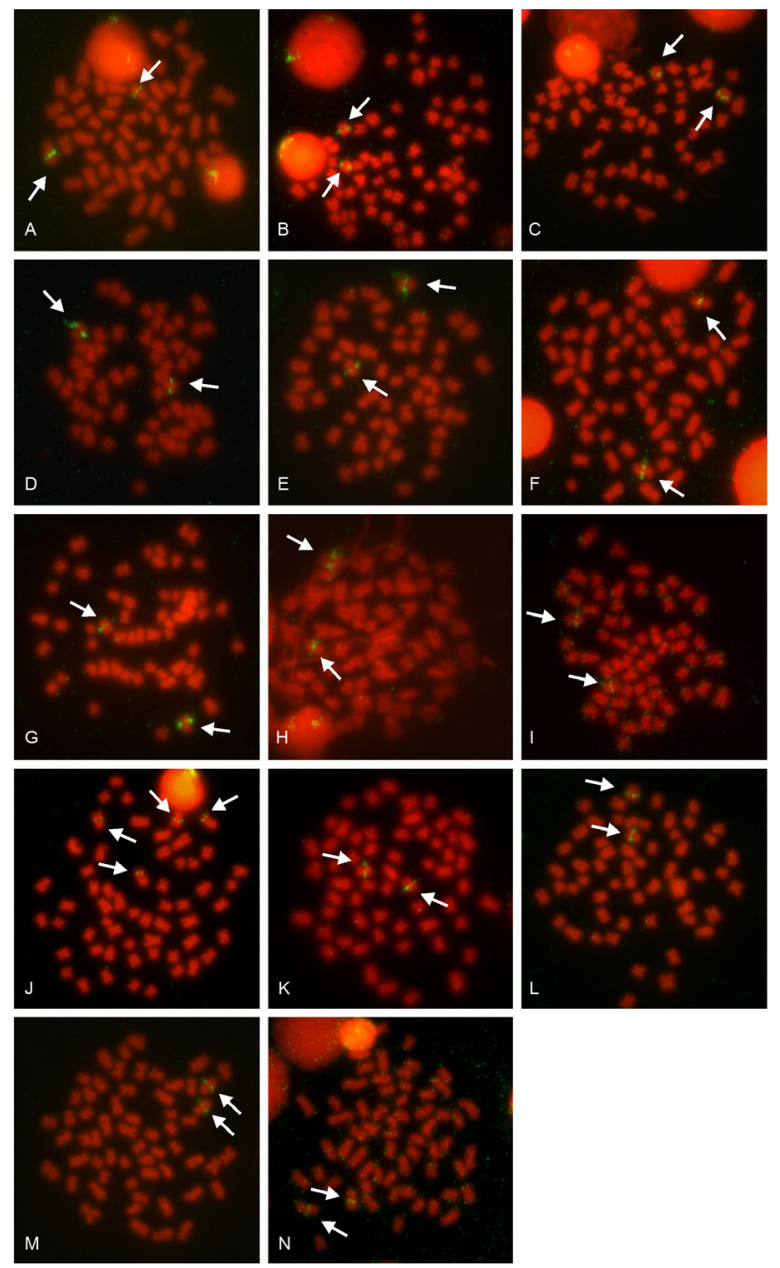

Figure 8. Somatic metaphases of Rhamdia quelen. Arrows indicate the 5S rDNA sites identified by FISH in the populations from A. Angra dos Reis, B. Araras, C. Botucatu, D. Oeste river - Cascavel, E. Sangão stream Cascavel, F. Colina, G. Guapiara, H. Iguape, I. Ipeúna, J. Mariápolis, K. Piquete, L. Paraíba do Sul River, M. São José River, N. Santo Antônio do Pinhal. 
Using C-banding, we observed small amounts of constitutive heterochromatin in all populations, represented by faint blocks distributed preferentially on NORs and close to centromeres. Terminal and interstitial C-bands were also visualized on some chromosomes. No cytogenetic marker was detected based on the C-bands within the standard karyotypes, demonstrating that $\mathrm{C}$-banding in the A chromosomal complement does not differentiate these populations (Figure 9).

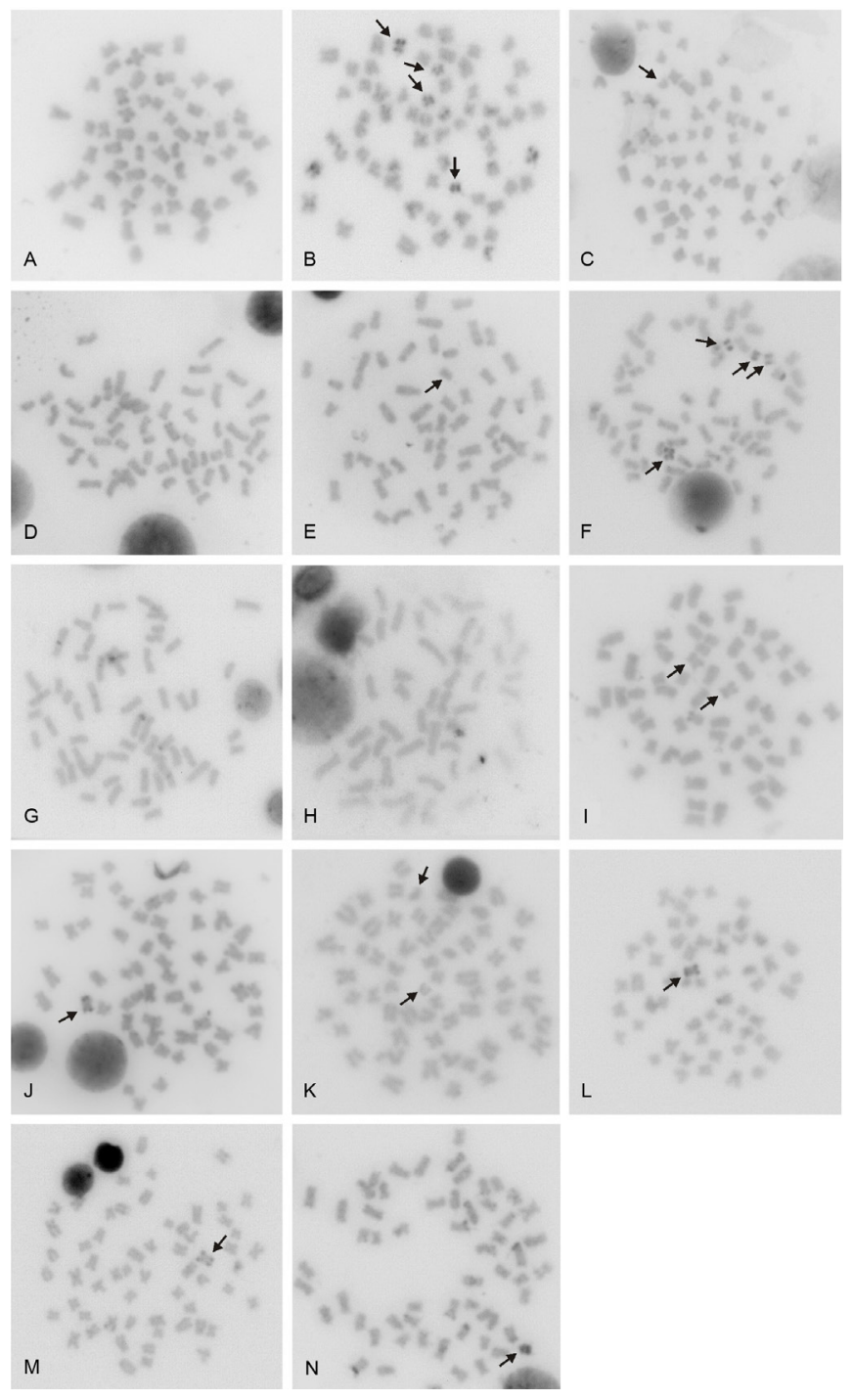

Figure 9. C-banded somatic metaphases in the populations of Rhamdia quelen from A. Angra dos Reis, B. Araras, C. Botucatu, D. Oeste river - Cascavel, E. Sangão stream - Cascavel, F. Colina, G. Guapiara, H. Iguape, I. Ipeúna, J. Mariápolis, K. Piquete, L. Paraíba do Sul River, M. São José River, N. Santo Antônio do Pinhal. Arrows indicate the supernumerary chromosomes. 
The supernumerary chromosomes that we identified were characterized by both intraand interindividual numerical variation within those populations of $R$. quelen that bore them. The largest number of these chromosomes (five) was found in the populations from Pardo and MogiGuaçu basins. In all populations, the additional chromosomes were metacentric and varied in size; usually, they were medium-sized, though sometimes they were small chromosomes (Table 1). In both cases, some supernumerary chromosomes could only be identified precisely after Cbanding, as they were similar in size and shape to the chromosomes of the standard karyotype.

Three patterns of C-banding were observed in the supernumerary chromosomes: 1) partially heterochromatic chromosomes, with heterochromatin at terminal regions of both arms in all medium-sized supernumerary chromosomes and in some small ones; 2) totally euchromatic chromosomes, which were observed only in small elements, and 3) totally heterochromatic chromosomes, identified only in the small supernumerary chromosomes (Figures 9 and 10).

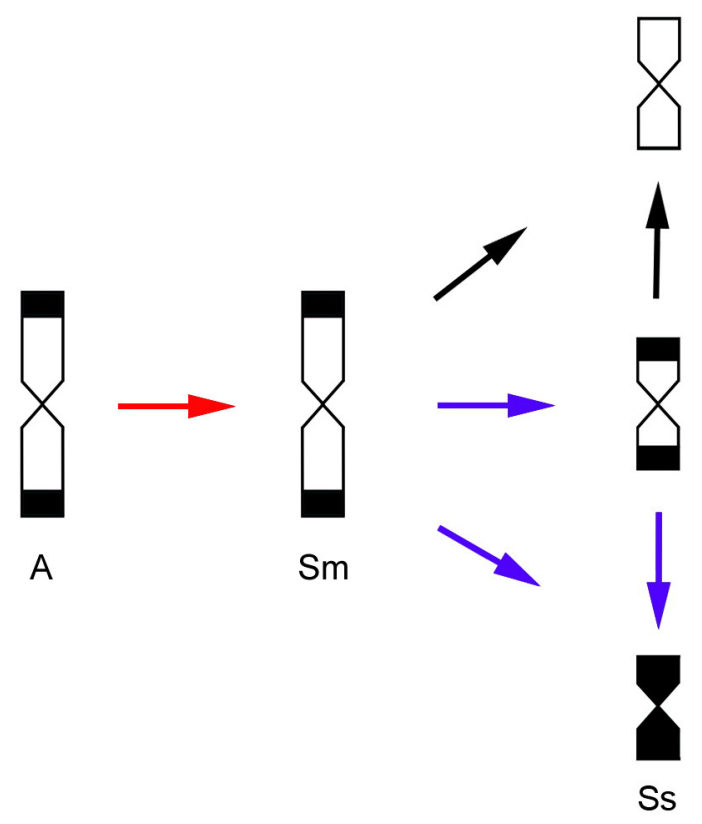

Figure 10. Schematic representation of the putative origin of supernumerary medium-sized metacentric chromosomes $(\mathrm{Sm})$ in Rhamdia quelen from a non-disjunction event (red arrow) in a medium-sized metacentric chromosome from the standard complement (A). Afterwards, the supernumerary chromosomes followed independent evolutionary pathways, inasmuch as they remained as medium-sized metacentric chromosomes or underwent modifications in size ( $\mathrm{Ss}=$ small supernumerary) and structure, like loss of euchromatin (blue arrows) or heterochromatin (black arrows). The dark regions in the figure indicate the heterochromatic blocks.

\section{DISCUSSION}

The modal chromosomal number of Siluriformes is $2 \mathrm{n}=56$, which according to Oliveira and Gosztonyi (2000) represents the ancestor diploid value within this group. Variations around this diploid number are usually associated with speciation processes and could 
be a result of either chromosomal rearrangements or polyploidization (Oliveira et al., 1988).

The chromosome number in Heptapteridae ranges from $2 \mathrm{n}=42$ to $2 \mathrm{n}=58$ (Oliveira, 2003). While some species in this family, such as the representatives of the genera Pimelodella and Imparfinis, show a remarkable variation in the diploid number, $R$. quelen invariably presents $2 \mathrm{n}=58$ chromosomes in all the populations that have been analyzed thus far. Since $R$. quelen is the most widely studied species, cytogenetically among the heptapterids, maintenance of this diploid number can be regarded as characteristic of this species.

In spite of the conservative diploid number, R. quelen has accentuated variability in the chromosome composition, with a predominance of bi-armed chromosomes. A similar situation is observed in other Siluriformes groups, such as the Auchenipteridae, Doradidae, Pimelodidae, and Pseudopimelodidae (Oliveira, 2003), as well as in some Characiformes, such as Anostomidae, Chilodontidae, Paradontidae, and Prochilodontidae (Martins et al., 2000). Variations involving the karyotype formulae, with maintenance of diploid numbers, indicate that nonRobertsonian rearrangements play a major role in chromosome evolution. Chromosomal inversions (either peri- or paracentric) have been considered the main mechanisms of karyotypic changes within some Siluriformes groups (Garcia and Moreira-Filho, 2008).

We observed various karyotypic formulae in the populations of $R$. quelen (Table 1). Two formulae were detected in the lower Paraná River basin $(32 \mathrm{~m}+8 \mathrm{sm}+12 \mathrm{st}+6 \mathrm{a}$ and $36 \mathrm{~m}$ $+10 \mathrm{sm}+12 \mathrm{st})$, three in the upper Paraná River basin $(34 \mathrm{~m}+16 \mathrm{sm}+8 \mathrm{st}, 36 \mathrm{~m}+10 \mathrm{sm}+12 \mathrm{st}$ and $40 \mathrm{~m}+10 \mathrm{sm}+8 \mathrm{st})$ and three in the Paraíba do Sul basin $(30 \mathrm{~m}+14 \mathrm{sm}+12 \mathrm{st}+2 \mathrm{a}, 36 \mathrm{~m}$ $+14 \mathrm{sm}+8 \mathrm{st}$ and $40 \mathrm{~m}+10 \mathrm{sm}+8 \mathrm{st})$. The karyotypic formula of $36 \mathrm{~m}+10 \mathrm{sm}+12 \mathrm{st}$ was the most frequent within the Paraná River basin, whereas $40 \mathrm{~m}+10 \mathrm{sm}+8 \mathrm{st}$ was the commonest formula in the Paraíba do Sul River basin.

Based on these data, together with previous reports (Garcia et al., 2003), we observed that karyotypes with fewer metacentric chromosomes (36 or less) present acrocentric chromosomes. When the sizes of the chromosomes in the distinct karyotypes were compared, the size proportion remained essentially the same. This feature can be considered a reliable indication that the changes in the chromosomal macrostructure probably derived from chromosomal inversions, making this kind of rearrangement the main mechanism of karyotypic modification in $R$. quelen.

A karyotypic pattern that characterizes $R$. quelen in a certain locality or hydrographic system has not been established. Populations that share the same karyotypic pattern in the standard complement differ in the number, size and C-banding pattern of supernumerary chromosomes. Based on sequencing data of mitochondrial genes, it was shown that the genus Rhamdia has diverged very recently (Perdices et al., 2002), suggesting these animals are undergoing an initial process of karyotypic differentiation that would reinforce their reproductive isolation, leading to speciation. This fish tends to form reduced populations inhabiting small water systems that can provide distinct environmental conditions, favoring allopatric speciation, thereby explaining the remarkable variability in their karyotypic structure and in the supernumerary chromosomes.

The observation that the same karyotypic formula is present in different localities could be explained by adaptive convergence or by the maintenance of an ancestral karyotype. The hypothesis concerning maintenance of an ancestral karyotype depends on a physical connection between the basins, in this case the lower and upper Paraná River. Headwater flow of rivers from the Paraná basin into the Paraíba do Sul basin (and vice-versa), as well as human activities, could result in the introduction of non-native forms into natural stocks. 
Various methodologies for the identification of NORs in lower vertebrates are currently used, including silver nitrate and base-specific fluorochrome staining and in situ hybridization with ribosomal probes. Analysis of NORs in fish has been useful for the karyotypic characterization of many species, with several reported cases of polymorphic NORs in terms of localization (Feldberg et al., 1992) and size (Moreira-Filho et al., 1984). NORs have also been reported on sex chromosomes (Artoni and Bertollo, 2002) and on supernumerary elements (De Oliveira Dantas et al., 2007).

There is a predominance of single NORs located on short arms of submeta/subtelocentric chromosomes in R. quelen (Maistro et al., 2002). Cases of multiple NORs, although rare, have been reported (Abucarma and Martins-Santos, 2001); despite a larger number of sites, they follow a similar distribution pattern. The number and location of NORs have also been confirmed by $\mathrm{CMA}_{3}$ staining and in situ localization of $18 \mathrm{~S}$ ribosomal genes (Garcia et al., 2003; Swarça et al., 2003; Moraes et al., 2007).

We observed that the nucleolar-bearing pair was conserved among populations with the same karyotype, and when the karyotypic formulae were different, the chromosomes of the NOR-bearing pair were of a similar size. Very likely, this chromosome pair is shared among the distinct chromosomal forms, since they are, in general, one of the few chromosomes with characteristic heterochromatic blocks, coinciding with NORs. However, this hypothesis can only be tested by more refined methodologies or microdissection.

There is little information about the localization of $5 \mathrm{~S}$ ribosomal genes in fish. The available data so far are quite variable for the known species, revealing that these genes may be present on a single chromosome pair (Martins and Galetti Jr., 1999; Kavalco et al., 2004), or in multiple pairs (Almeida-Toledo et al., 2002; Kavalco et al., 2004); syntenic or not to the 45S ribosomal genes (Kavalco et al., 2004), or even on sex chromosomes (Morán et al., 1996).

We observed a prevalence of pericentromeric 5S rDNA clusters. According to Martins and Galetti Jr. (1999), the localization of such genes in an internal position would give greater protection for these sequences, avoiding transposition and crossing events, usually more frequent in terminal regions. This could contribute to the highly conserved nature of these sequences in relation to the $45 \mathrm{~S}$ rRNA genes, which are commonly located in subtelomeric regions. The nonsyntenic localization of $45 \mathrm{~S}$ rRNA genes that we observed is a frequent condition in fish.

Except for the population from Mariápolis, which had two 5S rDNA-bearing chromosome pairs, possibly as a result of translocation, the $R$. quelen populations had a single pair carrying these genes, also maintaining a pericentromeric location. A high variability in both number and localization of $5 \mathrm{~S}$ ribosomal genes has been reported among genera and species within the Siluriformes (Kavalco et al., 2004). Rhamdia quelen is one of the few species that is conservative in the chromosome pair bearing $5 \mathrm{~S}$ rDNA cistrons. The maintenance of number and localization of $5 \mathrm{~S}$ ribosomal genes has also been reported in other fish groups, such as in the genus Astyanax (Almeida-Toledo et al., 2002).

Heptapterids usually have reduced amounts of heterochromatin, mainly distributed within pericentromeric and terminal regions (Swarça et al., 2003), although interstitial marks (Vissoto et al., 1999) and polymorphic heterochromatic regions (Vasconcelos and Martins-Santos, 2000) have also been reported. Most representatives of this fish group have small chromosomes, and the bands are usually faint, hindering precise observation of heterochromatin segments.

Studies made of $R$. quelen have revealed small amounts of heterochromatin spread throughout the chromosomes, while NORs comprise one of the few regions in the heterochromatin 
that are clearly visible (Fenocchio et al., 2002). In some populations lacking supernumerary chromosomes, one or two pairs of medium-sized metacentric chromosomes carry conspicuous heterochromatic blocks at a terminal position on both arms (Garcia et al., 2003, Martinez et al., 2008).

Supernumerary chromosomes are a karyotypic feature that have been detected in several populations of $R$. quelen from different hydrographic systems. Since these chromosomes share a similar morphology and a C-banding pattern showing divergent karyotypic structure among populations (this paper; Maistro et al., 2002; Fenocchio et al., 2003), they apparently have a common origin, prior to chromosomal diversification within the group. Consequently, the finding of distinct supernumerary chromosomes in populations with the same karyotypic formulae appears to be a good indication that these chromosomes evolved independently.

In general, specimens of $R$. quelen from the same population share a single type of supernumerary chromosome; the simultaneous presence of more than one type of B chromosome in the same individual has never been reported. The supernumerary chromosomes of $R$. quelen can vary in number among cells of individuals, as observed in all populations reported here, indicating that these chromosomes have an irregular behavior during cell division, probably because they lack Mendelian segregation (Jones and Rees, 1982). Other fish groups, such as Astyanax and Prochilodus, can bear more than one type of B chromosome within a population (Néo et al., 2000); in some cases they present mitotic stability or even segregation distortion between sexes (Moreira-Filho et al., 2004).

Currently, there are hypotheses about the possible origin of supernumerary chromosomes. The most accept ones refer to non-disjunction of an autosomal chromosome and the formation of isochromosomes (Carvalho et al., 2008). According to Moreira-Filho et al. (2004), since most supernumerary chromosomes are metacentric, this would strongly favor their origin from isochromosomes. Maistro et al. (2002) also proposed that the extra chromosomes of $R$. quelen are isochromosomes formed through a transverse division in the centromeric region of one chromosome in the standard karyotype bearing terminal heterochromatic blocks, thus explaining the biterminal C-bands on these supernumerary chromosomes.

According to Abucarma and Martins-Santos (2001) and Maistro et al. (2002), the heterochromatin distribution at both terminal regions of metacentric chromosomes corresponds to the C-banding pattern of supernumerary chromosomes. However, besides such a banding pattern being totally euchromatic or totally heterochromatic, small metacentric chromosomes have also been observed in R. quelen (this paper; Abucarma and Martins-Santos, 2001; Garcia et al., 2003; Moraes et al., 2007).

Metacentric chromosomes bearing terminal heterochromatic regions on both arms have been reported in the karyotype of other species in the families Auchenipteridae, Doradidae, Heptapteridae, and Pimelodidae (de Souza et al., 2004), including some populations of $R$. quelen without supernumerary chromosomes (Martinez et al., 2008). Since the C-bands in these chromosomes are conspicuous and easily detected when compared to the reduced and faint terminal heterochromatic blocks in other chromosomes of $R$. quelen, the supernumerary chromosomes in this species might have been derived from the chromosomes in the standard karyotype, most likely, as a result of chromosomal non-disjunction. Afterwards, these extra chromosomes have probably undergone different evolutionary pathways, involving the loss of either euchromatic regions or terminal heterochromatin blocks. These events would explain the observation that medium-sized supernumerary chromosomes invariably present biterminal C-bands, while the small supernumerary chromosomes can be euchromatic, heterochromatic or partially heterochromatic (Figure 10). 
According to Silva and Yonenaga-Yassuda (2004), when the supernumerary chromosomes are formed by non-disjunction, a series of structural changes follows through mutations or chromosomal rearrangements, resulting in a complete lack of homology and pairing between the supernumerary and the standard chromosomes. These events could explain the absence of A chromosomes bearing biterminal C-bands in populations with supernumerary chromosomes and why they are still found in populations without additional chromosomes.

The presence of different supernumerary chromosomes in $R$. quelen and their considerable numerical variation (up to seven chromosomes per individual) could be related to the inert and dispensable nature of supernumerary chromosomes. Therefore, changes in their structure and number might not affect their carriers in a way that would fix these elements in the populations (Néo et al., 2000).

Our data, together with the available cytogenetic reports on $R$. quelen, indicate that many of the karyotypic features in this group are conserved, including diploid number, location and number of both NOR and 5S rDNA sites, and even the C-banding pattern in the standard chromosomes. The high degree of variability in the chromosomal macrostructure is likely to be caused by non-Robertsonian rearrangements, mainly inversions. Currently, it is not possible to establish a karyotypic pattern to differentiate the populations or the hydrographic basins in which they occur, since several chromosomal features are shared by these populations, including the presence, morphology and structure of supernumerary chromosomes. To accomplish this, such studies should be expanded in this fish group to include a larger distribution area within these hydrographic basins, since previous reports involve geographically distant populations and do not provide information that would allow us to infer about hybrid forms or gene flow among populations that share the same karyotypic formula but distinct supernumerary chromosomes.

In summary, this information about chromosome patterns and biodiversity of $R$. quelen raises interesting questions about the evolution of supernumerary chromosomes in this species.

\section{ACKNOWLEDGMENTS}

The authors thank Carlos Eduardo Lopes for his assistance in collecting the specimens. Research supported by Coordenação de Aperfeiçoamento de Pessoal de Nível Superior (CAPES), Conselho Nacional de Desenvolvimento Científico e Tecnológico (CNPq) and Fundação de Amparo à Pesquisa do Estado de São Paulo (FAPESP).

\section{REFERENCES}

Abucarma M and Martins-Santos IC (2001). Karyotype and B chromosome of Rhamdia species (Pisces, Pimelodidae) endemic in the River Iguaçu basin. Cytologia 66: 299-306.

Almeida-Toledo LF, Ozouf-Costaz C, Foresti F, Bonillo C, et al. (2002). Conservation of the 5S-bearing chromosome pair and colocalization with major rDNA clusters in five species of Astyanax (Pisces, Characidae). Cytogenet. Genome Res. 97: 229-233.

Artoni RF and Bertollo LA (2002). Evolutionary aspects of the ZZ/ZW sex chromosome system in the Characidae fish, genus Triportheus. A monophyletic state and NOR location on the W chromosome. Heredity 89: 15-19.

Bockmann FA (2007). Família Heptapteridae. In: Catálogo das Espécies de Peixes de Água Doce do Brasil (Buckup PA, Menezes NA and Ghazzi MS, eds.). Museu Nacional, Rio de Janeiro, 104-109.

Carvalho RA, Martins-Santos IC and Dias AL (2008). B chromosomes: an update about their occurrence in freshwater Neotropical fishes (Teleostei). J. Fish Biol. 72: 1907-1932.

De Oliveira Dantas ES, Vicari MR, Souza IL and Moreira-Filho O (2007). Cytotaxonomy and karyotype evolution in Moenkhausia Eigenmann, 1903 (Teleostei, Characidae). Nucleus 50: 509-522. 
de Souza L, Giuliano-Caetano L and Dias AL (2004). Banding chromosome pattern of two species of Pimelodus (Siluriformes, Pimelodidae) from the Paraná River basin of Brazil. Folia Biol. 52: 165-169.

Feldberg E, Porto JIR and Bertollo LAC (1992). Karyotype evolution in Curimatidae (Teleostei, Characiformes) of the Amazon region. I. Studies on the genera Curimata, Psectrogaster, Steindachnerina and Curimatella. Rev. Bras. Genet. 15: 369-383.

Fenocchio AS, Swarça AC, Dias AL and Cestari MM (2002). Caracterização Cromossômica (Giemsa, Bandas C, NORS, CMA3 e FISH) de Rhamdia quelen do Alto Rio Iguaçu (Estado do Paraná). In: Anais do IX Simpósio de Citogenética e Genética de Peixes, Universidade Estadual de Maringá, Maringá.

Fenocchio AS, Bertollo LAC, Takahashi CS, Dias AL, et al. (2003). Cytogenetic studies and correlate considerations on Rhamdiinae relationships (Pisces, Siluroidei, Pimelodidae). Cytologia 68: 363-368.

Garcia C and Moreira-Filho O (2008). Localization of ribosomal genes in three Pimelodus species (Siluriformes, Pimelodidae) of the São Francisco River: 5S genes as species markers and conservation of the 18S rDNA sites. Genet. Mol. Biol. 31: 261-264.

Garcia C, Moreira-Filho O, Bertollo LAC and Centofante L (2003). B chromosomes and natural triploidy in Rhamdia sp. (Pisces, Siluriformes, Heptapteridae). Cytologia 68: 403-411.

Gold JR, Li YC, Shipley NS and Powers PK (1990). Improved methods for working with fish chromosomes with a review of metaphase chromosome banding. J. Fish Biol. 37: 563-757.

Hatanaka T and Galetti PM (2004). Mapping of the 18S and 5S ribosomal RNA genes in the fish Prochilodus argenteus Agassiz, 1829 (Characiformes, Prochilodontidae). Genetica 122: 239-244.

Howell WM and Black DA (1980). Controlled silver-staining of nucleolus organizer regions with a protective colloidal developer: a 1-step method. Experientia 36: 1014-1015.

Jones RN and Rees H (1982). B Chromosomes. Academic Press, London.

Kavalco KF, Pazza R, Bertollo LAC and Moreira-Filho O (2004). Karyotypic diversity and evolution of Loricariidae (Pisces, Siluriformes). Heredity 94: 180-186.

Levan A, Fredga K and Sandberg AA (1964). Nomenclature for centromeric position on chromosomes. Hereditas 52: 201-220.

Maistro EL, Oliveira C and Foresti F (2002). Cytogenetic analysis of A- and B-chromosomes of Rhamdia hilarii (Teleostei, Pimelodidae): C-banding, silver nitrate and $\mathrm{CMA}_{3}$ staining and restriction endonuclease banding. Cytologia 67: 25-31.

Martinez JF, Lui RL, Blanco DR, Traldi JB, et al. (2008). Análise Citogenética de uma População de Rhamdia quelen (Siluriformes, Heptapteridae) do Ribeirão dos Negros-SP. In: Anais do XII Simpósio de Citogenética e Genética de Peixes, 15-17 de outubro, Universidade Federal de Uberlândia, Uberlândia.

Martins C and Galetti PM Jr (1999). Chromosomal localization of 5S rDNA genes in Leporinus fish (Anostomidae, Characiformes). Chromosome Res. 7: 363-367.

Martins C, Venere PC, Mestriner CA, Cestari MM, et al. (2000). Chromosome relationships between Anostomidae and Chilodontidae fish (Characiformes). Cytologia 65: 153-160.

Moraes VP, Cereali SS, Froehlich O and Dias AL (2007). Cytogenetic characterization of Rhamdia quelen (Siluriformes, Heptapteridae) from the Bodoquena Plateau, Mato Grosso do Sul, Brazil. Genet. Mol. Res. 6: 627-633.

Morán P, Martinez JL, Garcia-Vazquez E and Pendas AM (1996). Sex chromosome linkage of 5S rDNA in rainbow trout (Oncorhynchus mykiss). Cytogenet. Cell Genet. 75: 145-150.

Moreira-Filho O, Bertollo LAC and Galetti PM Jr (1984). Structure and variability of nucleolar organizing regions in Parodontidae fish. Can. J. Genet. Cytol. 26: 564-568.

Moreira-Filho O, Galetti PM Jr and Bertollo LA (2004). B chromosomes in the fish Astyanax scabripinnis (Characidae, Tetragonopterinae): an overview in natural populations. Cytogenet. Genome Res. 106: 230-234.

Néo DM, Bertollo LA and Filho OM (2000). Morphological differentiation and possible origin of B chromosomes in natural Brazilian population of Astyanax scabripinnis (Pisces, Characidae). Genetica 108: 211-215.

Oliveira C (2003). Lista de Peixes Neotropicais de Água Doce. Available at [http://www.ibb.unesp.br/departamentos/ Morfologia/lab_pesq_biologia_e_genetica_de_peixes.php]. Accessed September 23, 2009.

Oliveira C and Gosztonyi AE (2000). A cytogenetic study of Diplomystes mesembrinus (Teleostei, Siluriformes, Diplomystidae) with a discussion of chromosome evolution in siluriforms. Caryologia 53: 31-37.

Oliveira C, Toledo LFA, Foresti F and Toledo SA (1988). Supernumerary chromosomes, Robertsonian rearrangement and multiple NORs in Corydoras aeneus (Pisces, Siluriformes, Callichthyidae). Caryologia 41: 227-236.

Perdices A, Bermingham E, Montilla A and Doadrio I (2002). Evolutionary history of the genus Rhamdia (Teleostei: Pimelodidae) in Central America. Mol. Phylogenet. Evol. 25: 172-189.

Pinkel D, Straume T and Gray JW (1986). Cytogenetic analysis using quantitative, high-sensitivity, fluorescence hybridization. Proc. Natl. Acad. Sci. U. S. A. 83: 2934-2938.

Pinna MCC (1998). Phylogenetic Relationships of Neotropical Siluriformes: Historical Overview and Synthesis of

Genetics and Molecular Research 9 (1): 365-384 (2010)

CFUNPEC-RP www.funpecrp.com.br 
Hypothesis. In: Phylogeny and Classification of Neotropical Fishes (Malabarba LR, Reis RE, Vari RP, Lucena ZMS, et al., eds.). EDPUCRS, Porto Alegre, 279-330.

Reis RE, Kullander SO and Ferraris CJ Jr (2003). Check List of the Freshwater Fishes of the South and Central America. EDIPUCRS, Porto Alegre.

Schmid M (1980). Chromosome banding in amphibia. IV. Differentiation of GC- and AT-rich chromosome regions in Anura. Chromosoma 77: 83-103.

Silfvergrip AMC (1996). A Systematic Revision of the Neotropical Catfish Genus Rhamdia (Teleostei, Pimelodidae). Stockolm University, Swedish Museum of Natural History, Stockolm.

Silva MJ and Yonenaga-Yassuda Y (2004). B chromosomes in Brazilian rodents. Cytogenet. Genome Res. 106: 257-263.

Sumner AT (1972). A simple technique for demonstrating centromeric heterochromatin. Exp. Cell Res. 75: 304-306.

Swarça AC, Fenocchio AS, Cestari MM and Dias AL (2003). Analysis of heterochromatin by combination of C-banding and CMA3 and DAPI staining in two fish species (Pimelodidae, Siluriformes). Genetica 119: 87-92.

Vasconcelos C and Martins-Santos IC (2000). Chromosome polymorphism in species of the Pimelodidae family (Pisces, Siluriformes). Hereditas 132: 103-109.

Vissoto PC, Foresti F and Oliveira C (1999). Supernumerary chromosomes in two species of the family Pimelodidae (Teleostei, Siluriformes). Chromosome Sci. 3: 9-13. 